\title{
EFFORTS TO INCREASE THE ABILITY TO CHOOSE A SCHOOL GROUP COUNSELING SERVICES THROUGH ADVANCED CLASS IX SMP 2 METRO STATE IN 2013
}

\author{
Rohima \\ SMP Negeri 2 Metro \\ rohimasmp2@gmail.com
}

\begin{abstract}
SMP Negeri 2 Metro In reality, there are many confused students choose a major program of advanced studies, especially for junior high school students. It is necessary to learn / coaching to the students to be able to choose the school accordingly. Researchers conduct action research through the Guidance Counseling Group in Class IX student of SMP Negeri 2 Metro. The experiment was conducted using two cycles. Recapitulation of data Selecting a program majoring in the process of learning / coaching from the first cycle to the second cycle, there is an increase of $57.06 \%$ to $86.35 \%$. The results of the data summary portfolio also increased from $33.32 \%$ to $83.33 \%$, and the recapitulation of learning outcomes of students who otherwise Completed Pass also risen from $54.54 \%$ increase to $96.96 \%$. Thus concluded indicator of success is to reach the target / as are $95 \%$ or more.
\end{abstract}

Keywords: guidance group, select schools, smp negeri 2 metro

\section{PENDAHULUAN}

Salah satu yang penting dilakukan siswa SMP kelas IX adalah memilih sekolah dan bersiap-siap untuk memasuki SMA atau SMK. Ini dimulai dengan memilih jurusan atau program pendidikan yang sesuai dengan bidang pekerjaan atau karir yang kelak dicita-citakan. Memilih dalam hal ini dapat diartikan sebagai suatu tindakan menentukan masa depan atas dasar keputusan masa kini. Tindakan itu sendiri merupakan proses yang menuntut kecermatan dan perhitungan yang tepat serta bimbingan. Melalui Bimbingan Konseling siswa diberikan bantuan untuk mematangkan persiapan tersebut secara lebih efektif sesuai dengan kondisi masingmasing. Kesalahan memilih jurusan dapat dipandang sebagai hambatan atau gangguan terhadap kelancaran dalam proses pemilihan jurusan.

$$
\text { Bimbingan dan Konseling }
$$
merupakan proses bantuan psikologis dan kemanusiaan secara ilmiah dan profesional yang diberikan oleh pembimbing kepada yang dibimbing (peserta didik) agar ia dapat berkembang secara optimal, yaitu mampu memahami diri, mengarahkan diri, dan mengaktualisasikan diri, sesuai tahap perkembangan, sifat-sifat, potensi yang dimiliki, dan latar belakang kehidupan serta lingkungannya sehingga tercapai kebahagiaan dalam kehidupannya.

Program pengembangan diri sebagai bagian integral dari program sekolah, terdiri dari dua kegiatan yaitu pengembangan diri dalam pelayanan Bimbingan dan Konseling (pelayanan BK) dan pengembangan diri dalam kegiatan Ekstra Kurikuler (Ekskul). Pelayanan BK adalah pelayanan bantuan untuk peserta didik baik secara perorangan maupun kelompok agar mampu dan mandiri berkembang secara optimal dalam bidang pengembangan kehidupan pribadi, kehidupan sosial, kegiatan dan 
kemampuan belajar dan perencanaan pengembangan karir, melalui berbagai jenis layanan dan kegiatan pendukung berdasarkan norma-norma yang berlaku. Kegiatan pengembangan diri dalam layanan BK harus diselerenggarakan oleh guru pembimbing yang telah memiliki ijazah Sarjana Pendidikan (S-1) bidang Bimbingan dan Konseling, dengan tujuan keprofesionalan dalam tugas melayani peserta didik. Adapun sebutan konselor adalah guru pembimbing yang telah memiliki ijazah Sarjana Pendidikan (S-1) bidang Bimbingan dan Konseling dan telah menyelesaikan program Pendidikan Profesi Konselor (PPK). Kegiatan Ekskul adalah kegiatan pendidikan di luar mata pelajaran untuk membantu pengembangan diri peserta didik sesuai dengan kebutuhan, potensi, bakat, dan minat mereka melalui kegiatan yang secara khusus diselenggarakan oleh pendidik dan atau tenaga pendidik lainnya yang berkemampuan dan berkewenangan di sekolah/madrasah.

Dalam masa-masa penjurusan ini, para guru disibukkan dengan banyaknya siswa, bahkan orang tua siswa yang berkonsultasi untuk meminta pendapat. Jurusan apa yang paling cocok untuk putra-putrinya. Kesibukan para guru terutama sehubungan dengan data yang tersedia, adakalanya hanya satu-satunya data Prestasi Belajar. Maka dengan adanya Layanan Bimbingan Konseling merupakan pelengkap atas pertimbangan di atas. Dengan data yang lengkap kemungkinan pertimbangan, pemilihan serta keputusan mendekati yang sebenarnya. Kemungkinan penjelasan dari pihak sekolah (guru/pembimbing, wali kelas, kepala sekolah), terhadap para siswa atau orang tua siswa lebih dapat diterima. Berdasarkan latar belakang inilah, maka dirumuskan masalah sebagai berikut: "Apakah melalui Layanan Bimbingan Konseling Siswa dapat memilih Jurusan/
Program IPA/IPS pada Siswa Kelas IX SMP Negeri 2 Metro".

Berdasarkan hal tersebut peneliti melakukan penelitian dengan judul "Pemecahan Masalah Kesulitan Memilih Program Jurusan Melalui Layanan Bimbingan Kelompok Pada Siswa Kelas IX SMP Negeri 2 Metro Tahun 2013”.

\section{METODE}

Metode dalam penelitian ini adalah metode Penelitian Tindakan Bimbingan Konseling (Class Action Research). Apabila sudah diketahui keberhasilan atau hambatan dalam tindakan yang dilaksanakan pada siklus pertama, peneliti kemudian mengidentifikasi permasalahan baru untuk menentukan rancangan siklus berikutnya. Kegiatan pada siklus kedua, dapat berupa kegiatan yang sama dengan sebelumnya bila ditujukan untuk mengulangi keberhasilan, untuk meyakinkan, atau untuk menguatkan hasil. Pada umumnya kegiatan yang dilakukan dalam siklus kedua mempunyai berbagai tambahan perbaikan dari tindakan sebelumnya yang ditunjukan untuk mengatasi berbagai hambatan atau kesulitan yang dihadapi.

\section{HASIL DAN PEMBAHASAN}

Berdasarkan permasalahan pertama tentang bagaimana gambaran aktivitas belajar siswa dalam kegiatan belajar mengajar pada materi ajar yang diajar dengan menggunakan model pembelajaran Model Layanan bimbingan kelompok, dapat dijelaskan berdasarkan hasil pengamatan pada siklus 1 dan siklus 2 yang cenderung mengalami peningkatan ke arah yang lebih baik, dimana rata-rata aktivitas siswa dapat dilihat. Rata-rata aktivitas siswa pada siklus 1 sampai siklus 2 cenderung mengalami peningkatan. Peningkatan aktivitas siswa tersebut, 
menunjukkan adanya minat dan antusias siswa dalam mengikuti pembelajaran pada dengan penerapan model pembelajaran Model Layanan bimbingan kelompok.

Berdasarkan hasil analisis dari beberapa siklus dan pembahasan, maka Model pembelajaran Layanan bimbingan kelompok dapat meningkatkan aktivitas belajar siswa Kelas IX SMP Negeri 2 Metro pada materi ajar Pemecahan Masalah Kesulitan Memilih Program Jurusan. Hal ini tergambar dari rata-rata aktivitas siklus I mencapai 2,91 dan meningkat sebesar 3,16 pada siklus II.

Model pembelajaran Layanan bimbingan kelompok dapat meningkatkan hasil belajar belajar siswa Kelas IX SMP Negeri 2 Metro. Peningkatan hasil belajar diperoleh dari hasil tes tindakan setiap siklus, dimana siklus I mencapai $74,83 \%$, dan siklus II mencapai 92,90 \%. Model pembelajaran Layanan bimbingan kelompok sudah terlaksana sesuai dengan skenario pembelajaran di Kelas IX SMP Negeri 2 Metro. Keterlaksanaan dari siklus I mencapai rata-rata sebesar $74,83 \%$, dan siklus II mencapai rata-rata sebesar 92,90\%.

\section{KESIMPULAN}

Berdasarkan hasil analisis dari beberapa siklus dan pembahasan, maka Model pembelajaran Layanan bimbingan kelompok dapat meningkatkan aktivitas belajar siswa Kelas IX SMP Negeri 2 Metro pada materi ajar Pemecahan Masalah Kesulitan Memilih Program Jurusan. Hal ini tergambar dari rata-rata aktivitas siklus I mencapai 2,91 dan meningkat sebesar 3,16 pada siklus II. Model pembelajaran Layanan bimbingan kelompok dapat meningkatkan hasil belajar belajar siswa Kelas IX SMP Negeri 2 Metro pada materi ajar. Peningkatan hasil belajar diperoleh dari hasil tes tindakan setiap siklus, dimana siklus I mencapai $74,83 \%$, dan siklus II mencapai 92,90 \%. Model pembelajaran Layanan bimbingan kelompok sudah terlaksana sesuai dengan skenario pembelajaran di Kelas IX SMP Negeri 2 Metro Keterlaksanaan dari siklus I mencapai rata-rata sebesar $74,83 \%$, dan siklus II mencapai rata-rata sebesar $92,90 \%$

Setelah melaksanakan penelitian dan melihat hasil yang didapatkan, maka peneliti menyarankan sebagai berikut :

1. Kepada para guru diharapkan dapat menerapkan Layanan bimbingan kelompok dalam proses pembelajaran Pemecahan Masalah Kesulitan Memilih Program Jurusan . Karena masih banyak orang tua siswa yang beranggapan bahwa jurusan SMA/ itu baik dan SMK itu kurang baik. Terkadang mereka tidak memikirkan bakat, minat dan kemampuan anaknya, bahkan cita-cita anaknya kedepan ditentukan oleh orang tuanya.

2. Kepada para peneliti selanjutnya diharapkan dapat melakukan penelitian tentang penerapan model pembelajaran yang lain yang dapat membangkitkan keaktifan siswa untuk belajar Pemecahan Masalah Kesulitan Memilih Program Jurusan.

\section{DAFTAR PUSTAKA}

Aidin Adlan.2012. Penelitian Tindakan Bimbingan Konseling. Kudus: Dita Kurnia

Ahmadi, Abu dan Supriyono W. 2004. Psikologi Belajar. Rineka Cipta: Jakarta

Arikunto, Suharsimi. Dkk., 2006. Penelitian Tindakan Bimbingan Konseling. Bumi Aksara. Jakarta.

Aqib, Zainal. 2009. Penelitian Tindakan Bimbingan Konseling. untuk : 
Guru. CV. Yrama Widya, Bandung.

Ngalim, Purwanto, M. 1984. PrinsipPrinsip dan Teknik Evaluasi Pengajaran. Remaja Rosdakarya: Bandung.

Oemar, Hamalik. 2003. Proses Belajar Mengajar. PT. Bumi Aksara: Jakarta.

Riduwan. 2004. Belajar Mudah Penelitian Untuk Guru-Karyawan dan Peneliti Pemula. Alfabeta: Bandung.

Syamsu yusuf L.N, (2009) Program Bimbingan dan Konseling di Sekolah, Rizqi press, Bandung 